Disclosure of Interests: Walter P. Maksymowych Grant/research support from: AbbVie, Novartis, Pfizer, and UCB, Consultant of: AbbVie, Boehringer Ingelheim, Celgene, Eli Lilly, Galapagos, Janssen, Novartis, Pfizer, and UCB, Employee of: Chief Medical Officer of CARE Arthritis Limited, Speakers bureau: AbbVie, Janssen, Novartis, Pfizer, and UCB, Xenofon Baraliakos: None declared, Ulrich Weber: None declared, Pedro M Machado Consultant of: PMM: Abbvie, Celgene, Janssen, Lilly, MSD, Novartis, Pfizer, Roche and UCB, Speakers bureau: PMM: Abbvie, BMS, Lilly, MSD, Novartis, Pfizer, Roche and UCB, Susanne Juhl Pedersen Grant/research support from: Novartis, Joachim Sieper Consultant of: AbbVie, Boehringer Ingelheim, Eli Lilly and Company, Janssen, Merck, Novartis, Pfizer, Roche, and UCB Pharma, Speakers bureau: AbbVie, Boehringer Ingelheim, Eli Lilly and Company, Janssen, Merck, Novartis, Pfizer, Roche, and UCB Pharma, Stephanie Wichuk: None declared, Denis Poddubnyy Grant/research support from: AbbVie, MSD, Novartis, and Pfizer, Consultant of: AbbVie, Bristol-Myers Squibb, Eli Lilly, MSD, Novartis, Pfizer, Roche, UCB, Speakers bureau: AbbVie, Bristol-Myers Squibb, Eli Lilly, MSD, Novartis, Pfizer, Roche, UCB, Martin Rudwaleit Consultant of: AbbVie, BMS, Celgene, Janssen, Eli Lilly, MSD, Novartis, Pfizer, Roche, UCB Pharma, Désirée van der Heijde Consultant of: AbbVie, Amgen, Astellas, AstraZeneca, BMS, Boehringer Ingelheim, Celgene, Cyxone, Daiichi, Eisai, Eli-Lilly, Galapagos, Gilead Sciences, Inc., Glaxo-Smith-Kline, Janssen, Merck, Novartis, Pfizer, Regeneron, Roche, Sanofi, Takeda, UCB Pharma; Director of Imaging Rheumatology BV, Robert B.M. Landewé Consultant of: AbbVie; AstraZeneca; Bristol-Myers Squibb; Eli Lilly \& Co.; Galapagos NV; Novartis; Pfizer; UCB Pharma, Joel Paschke: None declared, Robert G Lambert: None declared, Mikkel Ǿstergaard Grant/research support from: AbbVie, Bristol-Myers Squibb, Celgene, Merck, and Novartis, Consultant of: AbbVie, Bristol-Myers Squibb, Boehringer Ingelheim, Celgene, Eli Lilly, Hospira, Janssen, Merck, Novartis, Novo Nordisk, Orion, Pfizer, Regeneron, Roche, Sandoz, Sanofi, and UCB, Speakers bureau: AbbVie, Bristol-Myers Squibb, Boehringer Ingelheim, Celgene, Eli Lilly, Hospira, Janssen, Merck, Novartis, Novo Nordisk, Orion, Pfizer, Regeneron, Roche, Sandoz, Sanofi, and UCB

DOI: 10.1136/annrheumdis-2020-eular.6264

\section{OP0080 PERCEPTIONS SHOULD BE TAKEN INTO ACCOUNT WHEN INTERPRETING DISEASE ACTIVITY IN PATIENTS WITH AXIAL SPONDYLOARTHRITIS}

S. Kieskamp ${ }^{1}$, D. Paap ${ }^{1,2}$, M. Carbo ${ }^{1}$, F. Wink ${ }^{3}$, R. Bos ${ }^{3}$, H. Bootsma ${ }^{1}$, S. Arends ${ }^{1,3}$, A. Spoorenberg ${ }^{1,3} .{ }^{1}$ University Medical Center Groningen, Rheumatology and Clinical Immunology, Groningen, Netherlands; ${ }^{2}$ University Medical Center Groningen, Rehabilitation Medicine, Groningen, Netherlands; ${ }^{3}$ Medical Center Leeuwarden, Rheumatology, Leeuwarden, Netherlands

Background: Up to $40 \%$ of ankylosing spondylitis patients report persistently high pain scores of $>4$ (scale of $0-10$ ) even after responding to long-term TNF-alpha blocking therapy.[1] In other rheumatic diseases, nociplastic pain (due to altered functioning of the nervous system leading to peripheral and central sensitization) is common.[2] In axial spondyloarthritis (axSpA), patient illness and pain perceptions were shown to influence disease outcome.[3] Therefore, we hypothesized that central sensitization and patients' illness perceptions are associated with persistently high disease activity in axSpA.

Objectives: To investigate to what extent central sensitization, pain catastrophizing and patients' perceptions play a role in axSpA and to explore associations with disease activity.

Methods: Between April and September 2019, consecutive outpatients from the Groningen Leeuwarden axSpA (GLAS) cohort,[4] an ongoing large prospective cohort, were included in this study. Besides the standardized assessments, patients filled out three additional questionnaires: Central Sensitization Inventory (CSI), Pain Catastrophizing Scale (PCS) and Revised IIIness Perception Questionnaire (IPQ-R). Univariable and multivariable linear regression analyses were used to investigate the association of CSI, PCS and each of the eight subscales of the IPQ-R, and disease activity assessments ASDAS-CRP, BASDAI, and CRP. We corrected for the following potential confounders: gender, symptom duration, BMI, educational level, smoking status and HLA-B27 status.

Results: Of 171 included patients, 58\% were male, $79 \%$ were HLA-B27 positive, median symptom duration was 21 (IQR 10-32), mean ASDAS-CRP 2.1 \pm 1.0, mean BASDAI $3.9 \pm 2.2$ and median CRP 2.9 (IQR 1.2-6.3). Mean CSI score was $37.8 \pm 14.1$ (scale of $0-100$ ), and $44 \%$ of patients scored $\geq 40$ on the CSI.[5] Median PCS score was 15 (IQR 7-22) (scale of 0-52), median IPQ-R illness identity subscore 3 (IQR 2-4) (scale of 0-14) and mean IPQ-R treatment control subscore $18.1 \pm 3.4$ (scale of $5-25$ ). In univariable regression analysis, CSI and PCS scores and IPQ-R subscores all showed significant associations with ASDAS-CRP, and all except the IPQ-R subscale personal control showed significant associations with BASDAI. Only IPQ-R treatment control was significantly associated with CRP. Central sensitization, two IPQ-R subscales (perceived treatment control and the number of symptoms patients attributed to their axSpA: illness identity) and BMI were independently associated with disease activity assessments BASDAI $\left(R^{2}=0.46\right)$ and ASDAS-CRP $\left(R^{2}=0.36\right)$ (Figure 1).

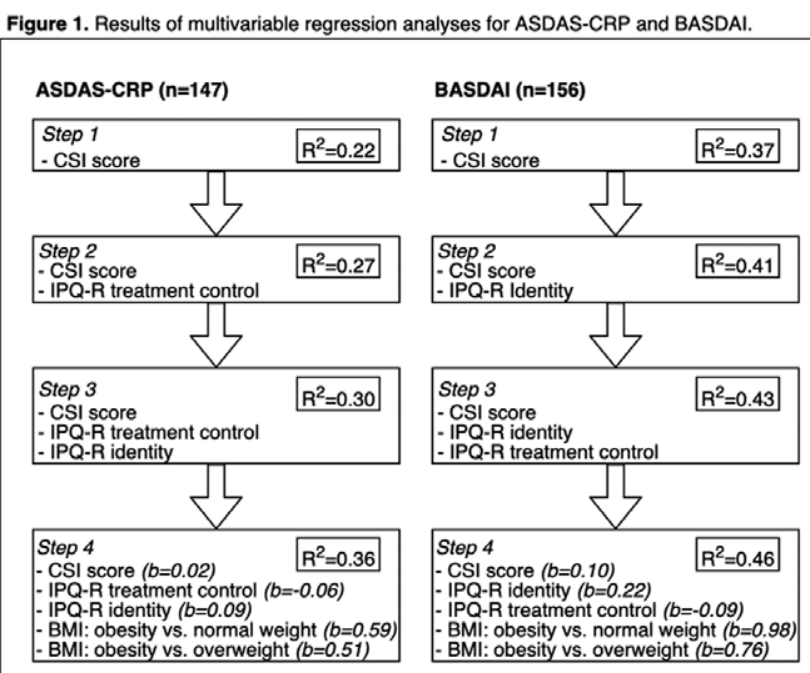

ASDAS-CRP: Ankylosing Spondylitis Disease Activity Score with C-reactive protein; BASDAI: Bath Ankylosing Spondylitis Disease Activity Score; CSI: Central Sensitization Inventory; IPQ-R: Revised IIIness Perception Questionnaire; BMI: Body Mass Index.

Conclusion: In this axSpA population with long-term disease, 44\% scored above the CSI cutoff point of 40 , indicating a high probability of central sensitization. CSI score, illness identity and treatment control were independently associated with disease activity assessments.

\section{References:}

[1] Arends S et al. Clin Exp Rheumatol 2017;35(1):61-8.

[2] Meeus M et al. Semin Arthritis Rheum 2012;41(4):556-67.

[3] Van Lunteren M et al. Arthritis Care Res (Hoboken) 2018;70(12):1829-39.

[4] Arends S et al. Arthritis Res Ther 2011;13(3):R94.

[5] Neblett R et al. J Pain 2013;14(5):438-45.

Disclosure of Interests: Stan Kieskamp: None declared, Davy Paap: None declared, Marlies Carbo: None declared, Freke Wink Consultant of: Abbvie, Janssen, Reinhard Bos: None declared, Hendrika Bootsma Grant/research support from: Unrestricted grants from Bristol-Myers Squibb and Roche, Consultant of: Consultant for Bristol-Myers Squibb, Roche, Novartis, Medimmune, Union Chimique Belge, Speakers bureau: Speaker for Bristol-Myers Squibb and Novartis. Suzanne Arends Grant/research support from: Grant/research support from Pfizer, Anneke Spoorenberg: None declared DOI: 10.1136/annrheumdis-2020-eular. 1684

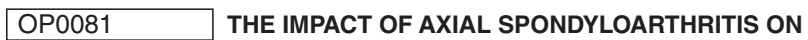 PATIENTS' SEXUAL LIFE: RESULTS FROM THE EUROPEAN MAP OF AXIAL SPONDYLOARTHRITIS (EMAS)}

M. Garrido-Cumbrera ${ }^{1,2}$, C. Bundy ${ }^{3}$, D. Poddubnyy ${ }^{4,5}$, S. Makri ${ }^{6}$,

R. Mahapatra ${ }^{7}$, S. Sanz-Gómez ${ }^{1}$, L. Christen ${ }^{8}$, C. J. Delgado-Domínguez ${ }^{1}$, V. Navarro-Compán ${ }^{9}$ on behalf of EMAS Working Group. ${ }^{1} \mathrm{Health} \&$ Territory Research (HTR), Universidad de Sevilla, Sevilla, Spain; ${ }^{2}$ Spanish Federation of Spondyloarthritis Associations (CEADE), Madrid, Spain; ${ }^{3}$ Cardiff University, Cardiff, United Kingdom; ${ }^{4}$ Charité - Universitätsmedizin Berlin, Berlin, Germany; ${ }^{5}$ German Rheumatism Research Centre, Berlin, Germany; ${ }^{6}$ Cyprus League Against Rheumatism, Nicosia, Cyprus; ${ }^{7}$ Axial Spondyloarthritis International Federation (ASIF), London, United Kingdom; ${ }^{8}$ Novartis Pharma AG, Basel, Switzerland; ${ }^{9}$ University Hospital La Paz, IdiPAZ, Madrid, Spain

Background: Axial Spondyloarthritis (axSpA) involves a great degree of functional limitation in daily activities and psychological health, which can impact patients' sexual life.

Objectives: To study the determinants of reduced frequency of sexual activity and intimacy since disease onset in axSpA patients. 